\title{
Aplikasi Smartphone Menggunakan Fintech Dalam Transportasi Jakarta Untuk Belanja Dalam Online Shop
}

\author{
Ersa Andhini Mardika ${ }^{1}$; Adrian Randy Pratama ${ }^{2}$; Muhammad Naufal Mu'azzi ${ }^{3}$; Erick$^{4}$; \\ Harco Leslie Hendric Spits Warnars ${ }^{5}$ \\ 1, 2, 3,4 Jurusan Sistem Informasi Bina Nusantara \\ ${ }^{5}$ Computer Science Department, BINUS Graduate Program - Doctor of Computer Science \\ 1ersa.mardika@binus.ac.id
}

\begin{abstract}
We propose that smartphone applications with technology combine the market of lecture transportation when public passenger transportation must benefit from coupons on the market. The existence of several strategies based on the online application provided makes users still a little interested in that. The survey methodology is also used to collect data from customers by stratified random sampling between two different groups (users and non-users). This discovery highlights the importance of ease of use and usability in developing attitudes.
\end{abstract}

Keywords: Mobile Application, Marketplace, Fintech, Transportation, Mobile Payment.

\begin{abstract}
ABSTRAK
Kami mengusulkan bahwa aplikasi smartphone dengan teknologi menggabungkan pasar transportasi ceramah ketika transportasi penumpang umum harus mendapat manfaat dari kupon di pasar. Adanya beberapa strategi berdasarkan aplikasi online yang disediakan membuat pengguna masih sedikit tertarik dengan hal itu. Metodologi survei juga digunakan untuk mengumpulkan data dari pelanggan dengan stratified random sampling antara dua kelompok yang berbeda (pengguna dan bukan pengguna). Penemuan ini menyoroti pentingnya kemudahan penggunaan dan kegunaan dalam mengembangkan sikap.
\end{abstract}

Kata kunci: Aplikasi seluler, pasar, fintech, transportasi, pembayaran seluler. 


\section{KILAT}

Vol. 8, No. 2, Oktober 2019, P-ISSN 2089-1245, E-ISSN 2655-4925

\section{PENDAHULUAN}

Hampir semua orang tahu kondisi di Jakarta, yaitu kemacetan atau kepadatan kendaraan. Salah satu alasannya adalah karena jumlah kendaraan meningkat dan keberadaan transportasi online tidak membantu mengurangi kemacetan tetapi membantu memfasilitasi perjalanan masyarakat. Untuk memahami kondisi seperti ini, kita perlu berinteraksi dengan pengguna kendaraan pribadi, publik, dan online. Dari interaksi yang kami lakukan, kami bisa mengetahui bagaimana perasaan mereka saat berada di Jakarta seperti ini. Kami mencari tahu apakah masalah ini berasal dari kesalahan pemerintah atau kesalahan masyarakat? Menyalahkan salah satu pihak bukan untuk menyelesaikan masalah. Meskipun tidak selalu menjadi masalah, satu pihak benar dan pihak lain salah. Dengan ini kita dapat lebih memahami apa yang mereka butuhkan dan bagaimana membuat aplikasi seluler yang baik untuk mereka. Karena itu kami mencari ide untuk menyelesaikan masalah dan kami menemukan ide tentang cara membuat sistem transportasi umum yang lebih baik di Jakarta dengan sistem pembayaran yang cerdas.

Bagaimana cara kerja sistem pembayaran pintar yang digunakan untuk kita? jadi sistem pembayaran terdiri dari QR Code dan Smart Card. Pengguna dengan mudah melakukan transaksi melalui aplikasi dengan kode QR untuk pembayaran transportasi umum. Sebelum melakukan pembayaran, pengguna harus menyiapkan saldo yang cukup dalam Aplikasi atau Kartu Cerdas. Aplikasi ini juga menawarkan kerja sama untuk pasar melalui titik-titik yang diperoleh dan ditukar dari menggunakan transportasi usia sehingga tidak hanya memfasilitasi masyarakat tetapi juga bermanfaat. Aplikasi ini dimaksudkan untuk membantu orang melakukan perjalanan sehari-hari dengan mudah tanpa merasakan kemacetan lagi. Sehingga mereka dapat melakukan perjalanan dengan nyaman dan tenang, bahkan tidak menyia-nyiakan terlalu banyak waktu atau terlambat untuk tiba di tempat tujuan. Saat ini, transportasi online seperti Grab, Gojek, My Blue Bird dan lainnya. Itu bisa menjadi contoh bahwa banyak yang menyadari masalah ini.

Desain aplikasi ini yang kami buat untuk pengguna dapat dengan mudah menggunakannya. Bahkan bagi pengguna yang belum pernah memiliki pengalaman dalam aplikasi seperti ini atau tidak mengerti cara menggunakannya sebelumnya, mereka dapat belajar menggunakannya dengan mudah. Karena ada prosedur untuk penggunaannya dan dapat diimplementasikan sesegera mungkin untuk perjalanan harian mereka. Aplikasi mobile adalah perangkat lunak TI yang dikembangkan khusus untuk sistem operasi seluler yang diinstal pada perangkat genggam. Desain aplikasi terkadang tidak memperhatikan aspek desain aplikasi yang baik, seperti pandangan yang berbeda dari produsen dan pengguna. Efektivitas dan efisiensi adalah dua aspek utama dalam membuat desain aplikasi yang baik. Untuk saat ini saya melihat bahwa tidak ada desain aplikasi mobile seperti ini, hanya ada aplikasi untuk transportasi online seperti Grab, Gojek, My Blue Bird dan lainnya. Teknologi yang dibuat akan diterapkan oleh pengembangan yang ingin mengembangkan aplikasi ini. Mungkin ini masih pilihan terbaik bagi masyarakat untuk mengurangi kemacetan di Jakarta atau daerah lain.

\section{PENELITIAN SEBELUMNYA}

Digitalisasi baru-baru ini memiliki dampak kuat pada industri jasa keuangan [1]. FinTech adalah inovasi baru dan menjanjikan. Pinjaman untuk P2P, e-wallet, bitcoin, T-commerce, mobile banking adalah semua teknologi keuangan yang mengubah hidup kita [2]. Dengan ini, organisasi Fintech, terutama startup, membentuk kembali industri jasa keuangan, menawarkan layanan yang berfokus pada pelanggan yang mampu menggabungkan kecepatan dan fleksibilitas [3]. Karena telah mengubah berbagai pola yang terkait dengan konsumsi kita karena ia mempopulerkan dan berkembang pada perangkat dan layanan seluler. Kami dapat membeli produk yang dibutuhkan di 
mana saja dan kapan saja selama 24 jam [4]. Penerapan teknologi baru yang hadir di seluruh dunia, terkait dengan revolusi dalam konektivitas nirkabel: pembayaran mobile [5]. Tujuan dari penelitian ini adalah untuk mengidentifikasi faktor-faktor pengguna "QR Code and Smartcard" untuk menerima layanan Fintech. Untuk mencapai tujuan ini, penelitian mengembangkan model dan penerimaan layanan Fintech dengan memanfaatkan teknologi melalui aplikasi mobile [6]. Selain itu, kami melakukan Concern for Information Privacy (CFIP), masalah yang semakin memburuk di industri keuangan, dan kemampuan individu sebagai variabel moderat untuk menguji dampaknya pada apa yang akan digunakan [7]. Bersama dengan kondisi promosi dan kredibilitas, dampak sosial memiliki dampak signifikan pada apa yang akan digunakan dalam penerimaan internet banking [8]. Sistem metode pembayaran elektronik interaktif, melalui nomor rekening kartu kredit yang digunakan dan melalui isyarat visual untuk menganalisis data pelanggan untuk menentukan jenis instrumen keuangan [9]. Dalam penelitian kami sebelumnya, kami telah mengembangkan aplikasi seluler untuk menangani kepadatan lalu lintas berdasarkan sistem yang kami modelkan. Oleh karena itu, skema pencegahan kemacetan lalu lintas telah diperkenalkan dalam ide ini [10].

\section{SISTEM YANG DIAJUKAN}

Dalam sistem yang diusulkan harus memiliki fitur-fitur berikut. Transaksi harus dilakukan dalam format aman antara berbagai pengguna di jaringan. Ini memberi pengguna fleksibilitas untuk mentransfer data melalui jaringan dengan sangat mudah dengan mengompresi sejumlah file. Ini juga menganalisis fungsionalitas dan aliran aplikasi yang sudah ada di domain yang sama dengan perangkat lunak dalam penelitian ini. Ini bertujuan untuk memilah fungsi dan aliran yang akan diadopsi dalam sistem yang sedang diteliti berdasarkan manfaat yang telah dihasilkan dari aplikasi yang dianalisis.

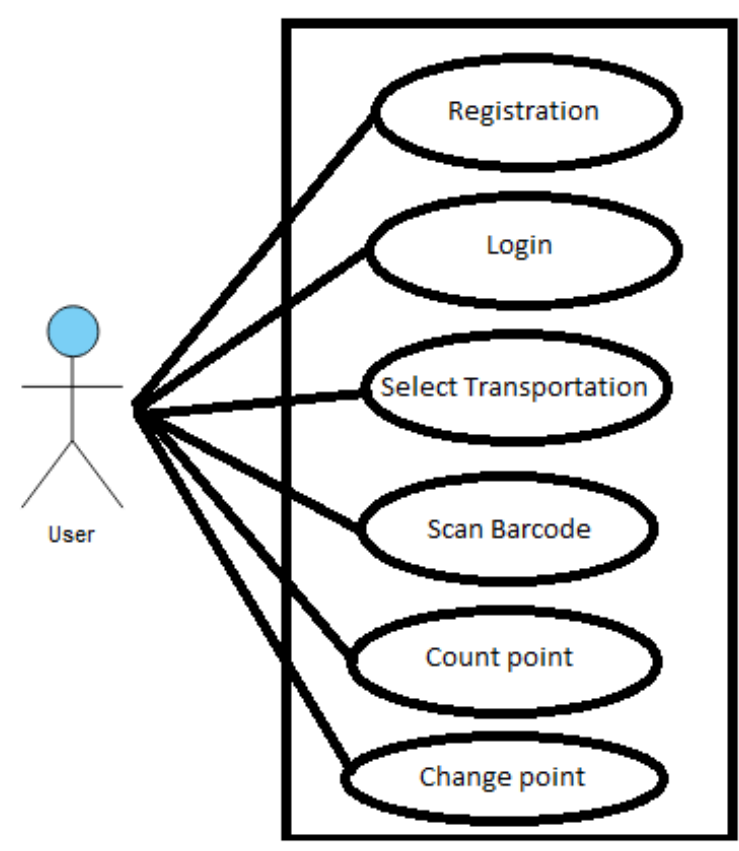

Gambar 1. Gunakan diagram khusus 


\section{KILAT}

Vol. 8, No. 2, Oktober 2019, P-ISSN 2089-1245, E-ISSN 2655-4925

Aplikasi smartphone menggunakan Fintech di Jakarta Transportasi adalah aplikasi mobile untuk masyarakat, tujuannya adalah menggunakan transportasi umum atau online setiap hari. Aplikasi sistem smartphone ini dibuat sederhana sehingga pengguna dapat menggunakannya dengan mudah dan dirancang agar menarik untuk digunakan. Dari gambar 1, jelaskan bagaimana pengguna mendaftarkan mereka di sistem, di mana mereka harus memasukkan data mereka untuk menghubungkan data pribadi ke sistem seperti nama, tanggal lahir, jenis kelamin, nomor telepon, email dan kata sandi.

Setelah mendaftar, pengguna harus memasukkan proses login dengan memasukkan identitas akun. Antara email dan kata sandi, ketika saya menggunakannya, itu tidak harus benar, karena keduanya saling terkait dan tidak dapat dipisahkan. Biasanya email pengguna tidak pernah berubah karena itu adalah identitas unik, tetapi kata sandi dapat diubah sesuai kebutuhan untuk mempertahankan akun keamanan. Sebelum melanjutkan pemilihan transportasi beberapa smartphone, terutama ponsel berbasis Android biasanya mengharuskan pengguna untuk mengaktifkan informasi lokasi dengan meminta aktivasi fitur GPS. Untuk era digital ini, kehadiran GPS atau Global Positioning System membuat proses navigasi jauh lebih mudah. Pengguna gadget dapat langsung menentukan lokasi mereka secara instan dan akurat.

Dalam sistem pemilihan transportasi pengguna dapat melihat bagaimana transportasi bekerja dan titik lokasi kendaraan yang ada di sana sesuai dengan tujuan. Setelah selesai, sistem secara otomatis menghitung poin yang diperoleh dari pemesanan transportasi dan pengguna dapat melihatnya secara langsung. Poin-poin yang diperoleh dari pemesanan transportasi dapat ditukar melalui kupon yang bekerja bersama di pasar, sistem akan berjalan secara otomatis sehingga pengguna tidak perlu menunggu lama untuk mendapatkan kupon.

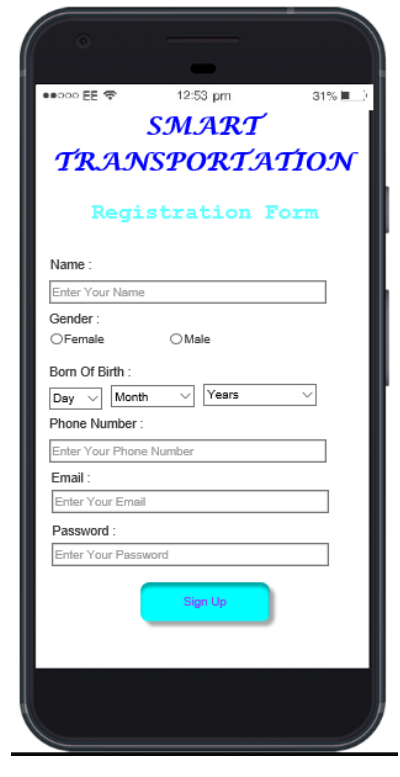

(a)

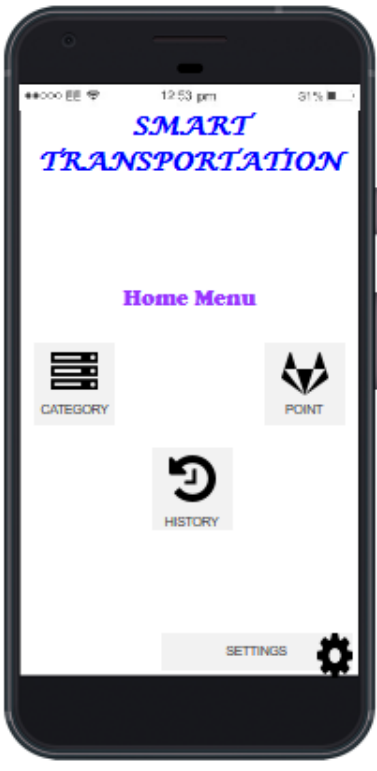

(b)

Gambar 2. (a) Formulir pendaftaran antarmuka pengguna (b) Menu Beranda

Gambar 2 desain antarmuka pengguna, tujuan menciptakan desain antarmuka pengguna adalah untuk membuat interaksi pengguna sesederhana dan seefisien mungkin, dalam hal mencapai tujuan pengguna. Karena proses desain harus seimbang antara fungsi teknis dan elemen visual (misalnya, model mental) untuk membuat sistem yang tidak hanya dapat beroperasi tetapi juga dapat digunakan 
dan disesuaikan dengan kebutuhan pengguna. Tampilan gambar 2 (a) adalah formulir pendaftaran antarmuka pengguna setelah mengunduh aplikasi ini, pengguna akan diminta memasukkan data pribadi seperti nama, tanggal lahir, jenis kelamin, nomor telepon, email, dan kata sandi. Periksa kembali semua data dan dokumen bahwa pengguna unggahan itu benar dan benar.

Setelah itu, klik tombol kirim untuk mengirim data ke sistem pendaftaran. Pengguna diharuskan mendaftar karena untuk menjaga keamanan akun dan tidak ada akun palsu untuk membuat pesanan fiktif yang dapat membahayakan pengemudi. Setelah mendaftar, pengguna akan melihat tampilan aplikasi secara keseluruhan. Dari gambar 2 (b) di antarmuka pengguna menu rumah menampilkan beberapa menu, yaitu transportasi kategori, riwayat, titik dan pengaturan. Menu kategori transportasi untuk melakukan pemesanan dan memilih kendaraan yang ingin Anda gunakan. Menu Riwayat untuk melihat riwayat data setelah bepergian. Sedangkan untuk titik menu, ini adalah bagian favorit bagi pengguna karena di sini pengguna dapat melihat total poin dan kupon yang akan diperoleh. Maka bagian menu dalam pengaturan berguna untuk mengubah bahasa atau data pengguna.

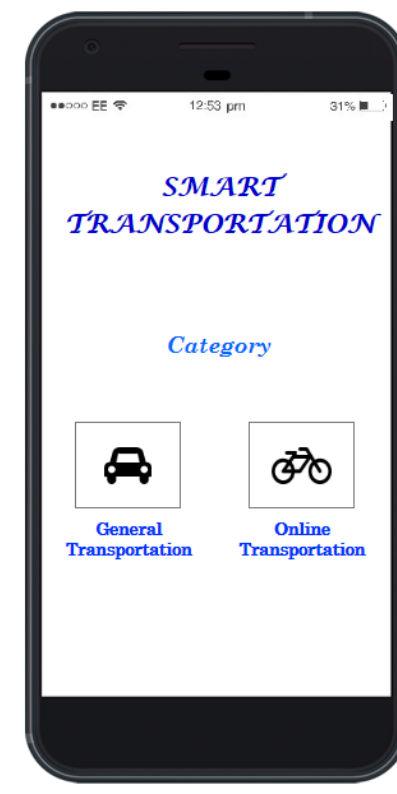

(a)

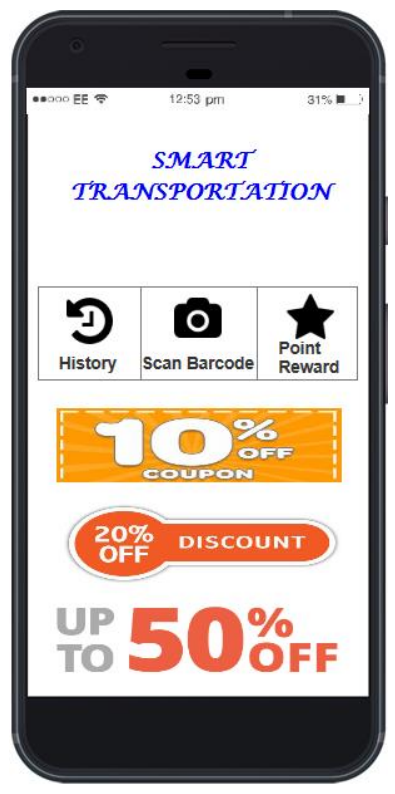

(b)

Gambar 3. (a) Transportasi kategori antarmuka pengguna (b) Pindai Kode QR

From figure 3 (a) user inteface category transportation, if the user selects this menu, the user will be asked to choose the vehicle to be used to reach the destination. The user must fill in the address and the vehicle and the address you want to go to. After determining the address, the rate and distance will appear on the screen. Then the user places an order on the screen and automatically and the application will detect the available vehicle. If the user wants to cancel the order, the user just simply presses the red cross button on the screen. Then if you continue to order, the user will be given a view such as making a booking. From figure 3 (b) the feature for making payments is the user interface Scan the QR Code. This QR Code payment system makes it easy for users to view balances, total payments, and balance balance after making payments. So users don't need to be confused with how much balance is left in the application. The scan code is also very easy to just open the camera view and then navigate to the existing barcode. This feature is very helpful for simple users without cash or debit cards, but only carries for existing gadgets and for those who don't understand existing smartcards. 


\section{KILAT}

Vol. 8, No. 2, Oktober 2019, P-ISSN 2089-1245, E-ISSN 2655-4925

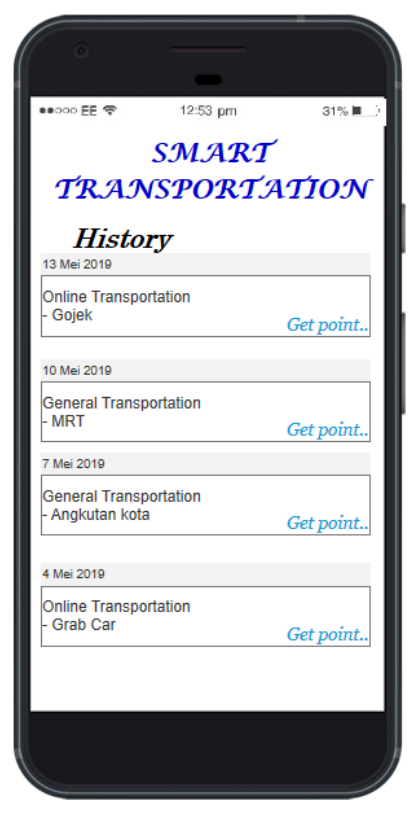

(a)

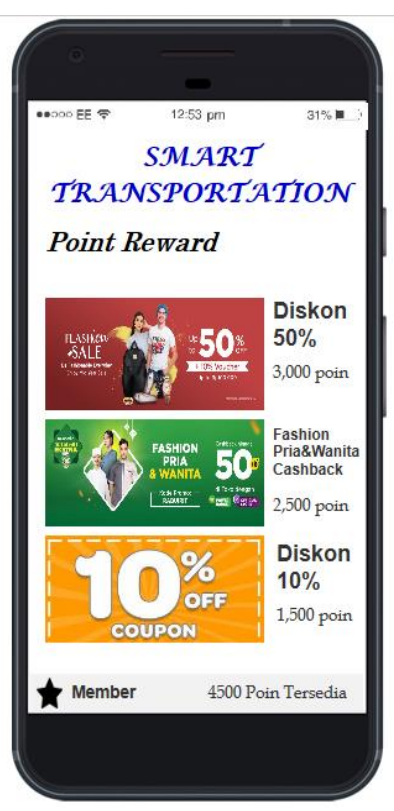

(b)

Gambar 4. (a) Riwayat pesanan (b) Poin hadiah

Dari gambar 4 (a) riwayat pesanan antarmuka pengguna saat pengguna selesai melakukan perjalanan, semua data yang dimasukkan ke dalam sistem dapat dilihat di menu riwayat ini. Menu riwayat ini tidak hanya untuk melihat data perjalanan tetapi dapat melihat poin yang diperoleh dari perjalanan sehingga pengguna tahu kendaraan mana yang mendapatkan lebih banyak poin. Ketika pengguna mendapat masalah dari pengemudi atau kendaraan melalui riwayat sistem, ia dapat melacak secara otomatis dengan laporan pengguna secara detail yang dikirim melalui email. Fitur histori ini sangat penting untuk aplikasi seperti ini karena dapat dengan mudah dilacak lebih cepat oleh sistem. Selanjutnya, Dari gambar 4 (b) dalam aplikasi ini adalah fitur poin hadiah. Fitur ini sangat disukai remaja hingga orang tua. Setiap pengguna yang melakukan perjalanan melalui aplikasi ini bisa mendapatkan poin dan dapat ditukar dengan kupon promo. Aplikasi ini dipenuhi dengan promo yang dapat dipertukarkan melalui suatu titik maka pengguna dapat menghabiskan di pasar. Fitur ini bisa dibilang showcase yang dimiliki oleh aplikasi. Cukup mudah dan mengesankan, karena aplikasi ini menawarkan semua promo yang mereka miliki dalam satu bagian. Mungkin tampilan antarmuka pengguna yang dibuat pada aplikasi ini sangat sederhana dan dapat memudahkan pengguna untuk menggunakannya. Kami juga menerima kritik dan saran untuk membuat desain aplikasi ini menjadi lebih baik di masa depan. 


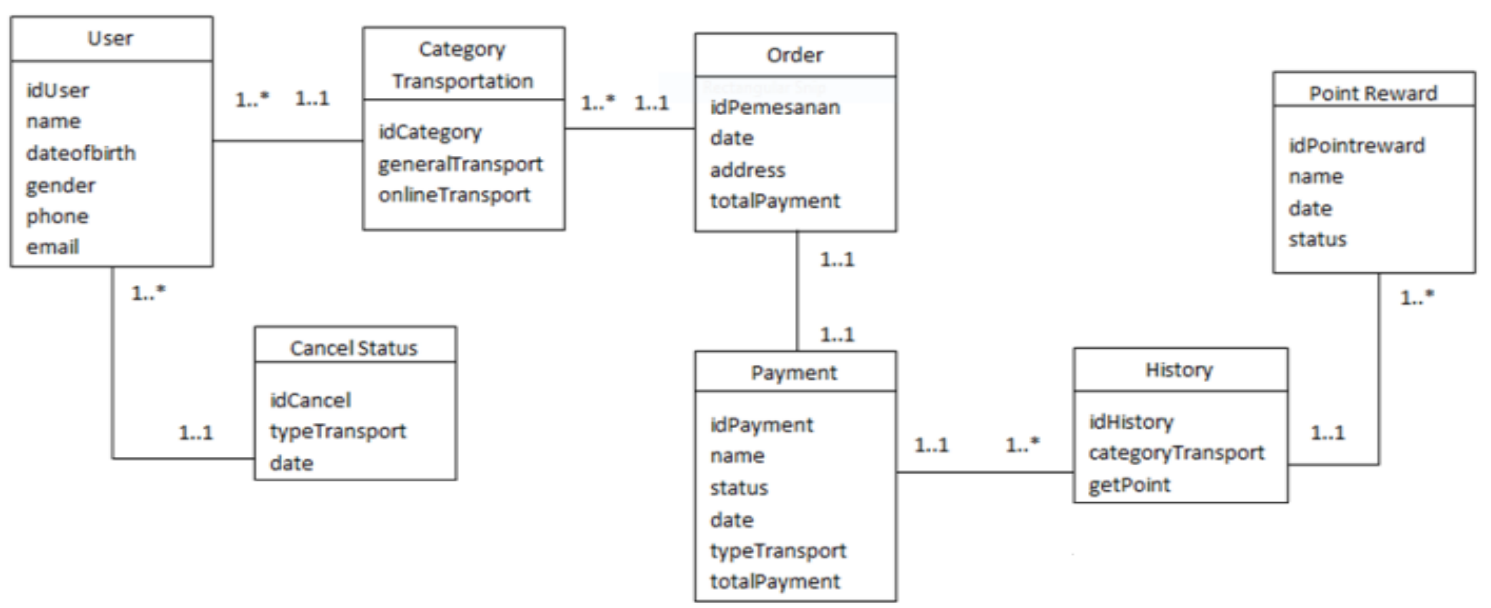

Gambar 5. Diagram kelas model database

Gambar 5 diagram basis data. Dalam layanan transportasi ini sistem juga memerlukan diagram database untuk melihat secara detail apa yang dibutuhkan dan pengembangan. Aplikasi sistem telepon pintar yang diusulkan membangun desain model basis data seperti, hubungan antara aplikasi pengguna dan pengaturan data yang akan dimasukkan, cara memproses hubungan dengan orang lain, sehingga membuat aplikasi ini berjalan dengan baik dan terstruktur. Sistem ini adalah bagian yang sangat penting dalam menjalankan aplikasi karena ini adalah desain terperinci dari suatu sistem. Pada Gambar 5 dapat dilihat hubungan antara kelas yang dapat terjalin pada sistem dan tentang itu kita memahami proses yang dibutuhkan di setiap kelas. Data khusus dalam sistem informasi yang diperoleh dari pengumpulan data sebelumnya menjadi referensi bagi manajer aplikasi sebagai bahan untuk keputusan untuk memusatkan atau memperluas bisnis, menentukan dan merekrut driver atau penerus layanan baru, dan pengembangan layanan. Tujuannya adalah untuk menyediakan akses yang mudah dan cepat, informasi selektif tentang faktor-faktor kunci dalam melaksanakan tujuan strategis perusahaan untuk manajemen eksekutif. Kemudian berikan kebijakan perusahaan secara umum atau kebijakan yang dimaksudkan pada level di bawah ini, yang kemudian akan diterjemahkan secara lebih spesifik oleh level di bawahnya dalam sistem informasi. Memanfaatkan sistem informasi untuk menentukan kebijakan untuk perbaikan keseluruhan perusahaan, seperti bekerja sama dengan perusahaan lain, dan menganalisis pesaing dan membuat kebijakan untuk bersaing.

\section{KESIMPULAN DAN SARAN}

Dalam analisis ini kami menyadari bahwa kehadiran teknologi komunikasi yang trendi di tengah-tengah masyarakat sangat menantang, bahkan dalam hal pemilihan transportasi untuk melakukan kebutuhan mobilitas. Layanan kemajuan teknologi komunikasi transportasi berbasis, dapat memudahkan orang untuk bepergian. Untuk mewujudkan transportasi yang nyaman dan aman, berbagai pihak terkait seperti pengemudi dan perusahaan lain mulai bersaing. Hal ini penting dilakukan, karena dengan menciptakan transportasi yang nyaman dan aman secara langsung akan menarik masyarakat untuk menggunakan layanan transportasi. Atas dasar itu, kami juga mewajibkan pengemudi untuk ikut serta dalam berbagai pelatihan yang diadakan oleh pihak terkait. Dengan fitur ini, keamanan pengguna akan dijamin. Aplikasi ini bekerja bersama dengan salah satu platform asuransi digital. Kolaborasi ini akan memberikan manfaat besar bagi pengguna, karena dapat memberikan perlindungan dalam bentuk jaminan keamanan dari kecelakaan, tindak pidana 


\section{KILAT}

Vol. 8, No. 2, Oktober 2019, P-ISSN 2089-1245, E-ISSN 2655-4925

(pengemis), dan seterusnya hingga maksimal bagi pengguna mulai dari pickup hingga tiba di tujuan. Di masa depan, transportasi berbasis manusia diharapkan dapat mengurangi kemacetan, polusi udara, dan parkir dengan memobilisasi lebih banyak orang dengan kendaraan yang lebih sedikit. Kemudian, dengan transportasi berbasis aplikasi online ini memberikan alternatif pemenuhan hak mobilitas warga. Kita semua sangat berharap bahwa sistem seperti ini dapat bertahan di masa depan dan menjadikan Jakarta lebih baik dari sekarang.

\section{UCAPAN TERIMAKASIH}

Penulis mengucapkan terima kasih kepada bapak Harco Leslie Hendric Spits Warnars, Computer Science Department - Doctor of Computer Science yang telah memberi dukungan yang membantu pelaksanaan penelitian dan atau penulisan artikel.

\section{DAFTAR PUSTAKA}

[1] T Puschman. (2017) Digitization of the Financial services industry. Journal of Business and Information System, Vol. 59, issues 1, pp 69-76

[2] B Nicoletti.(2017)The Future of Fintech. Journal of Financial services and Fintech, DOI 10.1007/978-3-319-51415-4_2

[3] arbitrage, and the Risk. Journal of Financial Economics, Vol. 130, no. 3, pages 453-483

[4] I Micu, A Micu (2016) Financial Technology and its implementation. Journal of SeaPratical Application of Science, issues no. 11, pages 379-384

[5] P, Ian (2016) The Rise of Fintech opprtunities and challenges. Journal of Financial Servisces Industry, JASSA, no. 3 2016: 15-21

[6] L Seong Hoon. L Dong-Wo (2015) Fintech- Conversation of finance industry . Journal of Korea Convergence Society Vol.6, no. 3, pages. 97-102, 2233-4890(pISSN)

[7] I Lee, Y Jae Shin (2018) Fintech : ecosystem, business models, investments decision and challenge. Journal of Business Horizon, Vol. 61, no. 1, pages. 35-46chist.

[8] A Yoris, J Robert (2008) The economics of mobile payment: Understanding stakeholder issues for an emerging financial technology application. Journal of Electronic Commerce Research and Application, Vol. 7, no. 2, pages. 141-164.

[9] E Young. (2015) Mobile easy Payment Services in the fintech Era. Journal of Informatization Policy, Vol. 22, no. 4, pagess. 22-24, 1598-3498(pISSN).

[10] A.V Ryabova. (2015) Emerging Fintech Market: types and features of new financial technologies. Journal of Economics and Social sciences, ISSN 2312-2978.

[11] R.PettyandJ. T.Cacioppo, Communication and Persuasion: Central and Peripheral Routes to Attitude Change, Springer-Verlag, 1986.

[12] F. D.Davis, Perceived Usefulness, Perceived Ease of Use, and User Acceptance ofInformation Technology, MIS quarterly, vol.13, no.3, pp.319-340, 1989.

[13] P. G.Schierz,O. Schilke, andB. W.Wirtz, Understanding Consume Acceptance of Mobile Payment Services: An Empirical Analysis, Electronic Commerce Research and Applications, vol.9, no.3, pp.209-216, 2010.

[14] Y. J.Joo,A. K. Chung, and Y. J.Jung, An Analysis of the Impact of Cyber University Students 'Mobile Self-efficacy, Mobility on Intention to Use in Mobile Learning Service 
Linked to E-learning, Journal of Korean Association of Computer Education, vol.18, no.1, pp.55-68, 2015.

[15] Y. S.Foon,andB. C. Y.Fah, Internet Banking Adoption in Kuala Lumpur:An Application of UTAUT Model, International Journal of Business and Management, vol. 6, no. 4, pp. $161,2011$.

[16] C.VanSlyke, J.T.Shim, R.Johnson, and J.Jiang, Concern for Information Privacy and Online Consumer Purchasing, Journal of the Association for Information Systems, vol.7, no.1, pp.415-444, 2006.

[17] A Bandura, Self-Efficacy: The Exercise of Control. New,York: W. H. Freeman,1997.

[18] D Chaffey. Fifth edition 2011. E-business \& E-commerce management-strategy, implementation and Practice. Cited: 20.09.2017.

[19] R Herman, 1987. Urban network-wide traffic variables and their relations. Transportation Science, 21, 1, 1--16.

[20] W Robertson. and W. J.Phillips. 2004. In Proceedings of International Workshop on Wireless Ad-Hoc Networks 2004.IEEE,Oulu,Finland. 